\title{
PENGARUH PAJAK, TUNNELING INCENTIVE DAN EXCHANGE RATE PADA KEPUTUSAN TRANSFER PRICING PERUSAHAAN
}

\author{
Marfuah \\ Accounting Department, Faculty Economics \\ Universitas Islam Indonesia \\ e-mail:marfuah@uii.ac.id \\ Andri Puren Noor Azizah \\ Accounting Department, Faculty Economics \\ Universitas Islam Indonesia \\ e-mail: andripuren.zezen@yahoo.com
}

\begin{abstract}
The objective of this research is to analyze the influence of tax, tunneling incentive and exchange rate on transfer pricing decision in manufacturing companies. The population of this study is all of the manufacturing companies listed with the Indonesia Stock Exchange from 2010 to 2012. Sampling method used in this study is purposive sampling. The results of logistic regression analysis demonstrate that out of the three hypotheses tested, only the second hypothesis shows a positive effect of tunneling incentive to the company transfer pricing decisions. The analysis of the first hypothesis demonstrates that tax has a significant negative effect on the company transfer pricing decisions. Furthermore, the analysis of the third hypothesis about the effect of exchange rate on transfer pricing decisions shows a positive effect but not significant.
\end{abstract}

Keywords: transfer pricing, tax, tunneling incentive, exchange rate

\begin{abstract}
Abstrak
Tujuan penelitian ini adalah untuk menguji pengaruh pajak, tunneling incentive dan exchange rate terhadap keputusan transfer pricing perusahaan manufaktur. Populasi sampel studi ini adalah semua perusahaan manufaktur yang terdaftar di Bursa Efek Indonesia pada tahun 2010 hingga 2012. Metode sampel yang digunakan pada studi ini adalah purposive sampling. Berdasarkan pada hasil analisis regresi logistik ditemukan bahwa dari tiga hipotesis yang diuji, hanya hipotesis kedua tentang pengaruh positip tunneling incentive terhadap transfer pricing yang didukung. Pengujian hipotesis pertama tentang pengaruh positip pajak terhadap transfer pricing, hasilnya justru berlawanan arah dengan yang diprediksi, yaitu pajak berpengaruh negatip signifikan terhadap keputusan transfer pricing perusahaan. Sementara pengujian hipotesis ketiga tentang pengaruh exchange rate terhadap transfer pricing menunjukkan arah positip tetapi tidak signifikan.
\end{abstract}

Kata kunci: transfer pricing, pajak, tunneling incentive, exchange rate

\section{PENDAHULUAN}

Fenomena globalisasi secara tidak langsung mendorong merebaknya konglomerasi dan divisionalisasi perusahaan. Dalam lingkungan perusahaan multinasional dan konglomerasi serta divisionalisasi terjadi berbagai transaksi antar anggota (divisi) yang meliputi penjualan barang dan jasa, lisensi hak dan harta tak ber- wujud lainnya, penyediaan pinjaman dan lain sebagainya. Transaksi-transaksi yang terjadi dalam lingkungan perusahaan seperti ini nantinya akan menyulitkan dalam penentuan harga yang harus ditransfer. Penentuan harga atas berbagai transaksi antar anggota atau divisi tersebut lazim disebut dengan transfer pricing (Mangoting 2000). 
Transfer pricing untuk barang maupun jasa merupakan salah satu dari perbedaan besar yang terjadi antara pengendalian manajemen operasi domestik dan luar negeri. Dalam operasi luar negeri, dibutuhkan beberapa pertimbangan penting lainnya untuk dapat sampai kepada suatu keputusan transfer pricing. Pertimbangan-pertimbangan tersebut diantaranya adalah pajak, tunneling incentive, dan exchange rate (Anthony dan Govindarajan 2011). Menurut Eiteman, Stonehill dan Moffett (2010), penetapan harga barang atau jasa yang ditransfer ke anak perusahaan asing dari suatu perusahaan terafiliasi disebut penetapan transfer pricing merupakan metode pertama yang paling utama dalam mentransfer dana keluar dari anak perusahaan asing.

Salah satu hal utama yang dihadapi dalam investasi asing adalah transfer pricing. Praktik transfer pricing ini pada awalnya dilakukan oleh perusahaan semata-mata hanya untuk menilai kinerja antar anggota atau divisi perusahaan, tetapi seiring dengan perkembangan zaman, praktik transfer pricing sering juga dipakai untuk manajemen pajak yaitu sebuah usaha untuk meminimalkan jumlah pajak yang harus dibayar (Harimurti 2007).

Dari sisi pemerintahan, transfer pricing diyakini mengakibatkan berkurang atau hilangnya potensi penerimaan pajak suatu negara karena perusahaan multi-nasional cenderung menggeser kewajiban perpajakannya dari negara-negara yang memiliki tarif pajak yang tinggi (high tax countries) ke negara-negara yang menerapkan tarif pajak rendah (low tax countries). Di pihak lain dari sisi bisnis, perusahaan cenderung berupaya meminimalkan biaya-biaya (cost efficiency) termasuk di dalamnya minimalisasi pembayaran pajak perusahaan (corporate income tax). Bagi korporasi multinasional, perusahaan berskala global (multi-national corporations), transfer pricing dipercaya menjadi salah satu strategi yang efektif untuk memenangkan persaingan dalam memperebutkan sumbersumber daya yang terbatas (Santoso 2004).

Tujuan utama dari perencanaan pajak multinasional adalah meminimalkan beban pajak seluruh dunia bagi perusahaan. Pajak memiliki dampak besar terhadap laba bersih dan arus kas perusahaan melalui pengaruhnya terhadap keputusan investasi asing, struktur keuangan, penentuan biaya modal, dan sebagainya (Eiteman, Stonehill, dan Moffett 2010). Oleh karena itu, adanya praktik transfer pricing inilah yang sering dikaitkan hubungannya dengan adanya pajak.

Tunneling juga berpengaruh terhadap transfer pricing. Gilson dan Gordon (2003) mengidentifikasi dua kemungkinan cara yang dapat dilakukan pemegang saham pengendali untuk mendapatkan manfaat privat atas kontrol dari kebijakan perusahaan yaitu melalui kebijakan operasi perusahaan dan kebijakan kontraktual dengan pihak lain. Bentuk-bentuk manfaat privat yang dapat diperoleh melalui kebijakan operasi perusahaan antara lain gaji dan tunjangan tinggi, bonus dan kompensasi besar, serta dividen. Sedangkan cara untuk memperoleh manfaat privat melalui kebijakan kontraktual antara lain dilakukan melalui tunneling. Tunneling merupakan transfer sumber daya keluar dari perusahaan untuk kepentingan pemegang saham pengendali (Johnson et al. 2000)

Arus kas perusahaan multinasional didenominasikan dalam beberapa mata uang dimana nilai setiap mata uang relatif kepada nilai dolar akan berbeda seiring dengan perbedaan waktu. Exchange rate yang berbedabeda inilah yang nantinya akan mempengaruhi praktik transfer pricing pada perusahaan multinasional. Sebagai contoh, sebagian besar perusahaan multinasional meminta pertukaran satu valuta dengan valuta yang lain untuk melakukan pembayaran, karena nilai tukar valuta yang terus-menerus berfluktuasi, jumlah kas yang dibutuhkan untuk melakukan pembayaran juga tidak pasti. Konsekuensinya adalah jumlah unit valuta negara asal yang dibutuhkan untuk membayar bahan baku dari luar negeri bisa berubah-ubah walaupun pemasoknya tidak merubah harga. Berdasarkan latar belakang tersebut maka tujuan penelitian ini adalah untuk menguji pengaruh pajak, tunneling incentive dan exchange rate terhadap keputusan transfer pricing perusahaan. 


\section{TINJAUAN PUSTAKA DAN PERUSMUSAN HIPOTESIS}

\section{Pengaruh Pajak terhadap Keputusan Transfer Pricing}

Berbagai penelitian mengenai faktor-faktor yang mempengaruhi keputusan transfer pricing perusahaan telah dilakukan. Yuniasih, Rasmini, dan Wirakusuma (2012) melakukan penelitian pada perusahaan manufaktur yang terdaftar di Bursa Efek Indonesia pada tahun 2008-2010. Hasil penelitian menemukan adanya pengaruh positif pajak terhadap keputusan transfer pricing perusahaan. Beban pajak yang semakin besar memicu perusahaan untuk melakukan transfer pricing dengan harapan dapat menekan beban tersebut.

Suatu perusahaan yang melakukan bisnis multinasional, dalam hal ini ekspor dan impor akan menghadapi berbagai jenis pajak. Perbedaan beban pajak dalam bisnis multinasional sudah biasa terjadi. Sehingga negaranegara dengan perusahaannya yang kurang maju sering mengenakan tarif pajak yang lebih rendah, sedangkan negara-negara dengan perusahaannya yang maju justru mengenakan tarif pajak yang tinggi.

Dengan adanya hal tersebut, maka perusahaan-perusahaan maju akan berpikir bagaimana caranya untuk menekan pajak mereka karena pajak merupakan pengurang laba. Apabila pajak dapat ditekan, maka dapat mengurangi cost perusahaan. Salah satu cara yang digunakan untuk menekan pajak adalah transfer pricing. Melalui transfer pricing ini perushaan multinasional yang bersangkut an dapat menggeser kewajiban perpajakannya dari anggota atau anak perusahaannya di negara-negara yang menetapkan tarif pajak yang lebih tinggi (high tax country) ke anggota atau anak perusahaannya di negaranegara yang menetapkan tarif pajak yang lebih rendah (low tax country).

Apabila dalam suatu perusahaan terdapat pajak yang tinggi, maka tingkat kegiatan transfer pricing perusahaan tersebut ke anggota atau anak perusahaannya yang menerapkan tarif pajak lebih rendah akan meningkat dan sebaliknya. Berdasarkan rumusan di atas maka hipotesis dalam penelitian ini adalah sebagai berikut:

H1: Pajak berpengaruh positif terhadap keputusan transfer pricing perusahaan

\section{Pengaruh Tunneling Incentive Terhadap Keputusan Transfer Pricing}

Yuniasih, Rasmini, dan Wirakusuma (2012) menemukan adanya pengaruh positif tunneling incentive pada keputusan transfer pricing perusahaan. Transaksi pihak terkait lebih umum digunakan untuk tujuan transfer kekayaan daripada pembayaran dividen karena perusahaan yang terdaftar harus mendistribusikan dividen kepada perusahaan induk dan pemegang saham minoritas lainnya. Kondisi yang unik dimana kepemilikan saham pada perusahaan publik di Indonesia cenderung terkonsentrasi sehingga ada kecenderungan pemegang saham mayoritas untuk melakukan tunneling.

Salah satu bentuk tunneling adalah peran pemegang saham pengendali dalam memindahkan sumber daya perusahaan melalui transaksi hubungan istimewa. Transaksi tersebut mencakup kontrak penjualan seperti transfer pricing. Dengan diadakannya tunneling oleh pemegang saham pengendali, maka tidak dilakukan pembayaran dividen sehingga pemegang saham minoritas kurang diuntungkan.

emegang saham pengendali melakukan kegiatan tunneling bertujuan untuk mengalihkan asetnya sementara ke anggota atau anak perusahaan dengan transfer pricing agar dapat menekan beban-beban yang nantinya dapat mengurangi laba perusahaan. Apabila kegiatan tunneling semakin banyak dilakukan, maka kegiatan pengalihan dengan transfer pricing juga akan meningkat dan sebaliknya.

Berdasarkan rumusan di atas maka hipotesis dalam penelitian ini adalah sebagai berikut:

H2: Tunneling incentive berpengaruh positif terhadap keputusan transfer pricing perusahaan.

\section{Pengaruh Exchange Rate Terhadap Keputusan Transfer Pricing}

Exchange rate memiliki dua efek akuntansi, yaitu untuk memasukkan transaksi mata uang 
asing dan pengungkapan keuntungan dan/atau kerugian yang dapat mempengaruhi keuntungan perusahaan secara keseluruhan. Akibatnya, perusahaan multinasional mungkin mencoba untuk mengurangi risiko nilai tukar (exchange rate) mata uang asing dengan memindahkan dana ke mata uang yang kuat melalui transfer pricing untuk memaksimalkan keuntungan perusahaan secara keseluruhan (Chan, Landry, dan Jalbert 2002). Berdasarkan rumusan di atas maka hipotesis dalam penelitian ini adalah sebagai berikut:

H3: Exchange rate berpengaruh positif terhadap keputusan transfer pricing perusahaan.

\section{Model Kerangka Pemikiran Penelitian}

Model kerangka pemikiran penelitian yang menggambarkan hubungan antara variabel independen terhadap variabel dependen disajikan pada Gambar 1.

\section{METODA PENELITIAN}

Pada bagian ini dibahas populasi dan sampel penelitian, jenis dan sumber data, variabel dan pengukurannya, hipotesis operasional serta metode analisis data.

\section{Populasi dan Sampel}

Populasi penelitian ini adalah seluruh perusahaan yang terdaftar di Bursa Efek Indonesia dari tahun 2010 sampai dengan tahun 2012. Pengambilan sampel dilakukan dengan menggunakan metode purposive sampling, yaitu teknik pengambilan sampel dengan mempertimbangkan kriteria-kriteria, yaitu; (1) Perusahaan manufaktur yang terdaftar di Bursa Efek Indonesia dari tahun 2010 sampai dengan tahun 2012, (2) Perusahaan sampel dikendali kan oleh perusahaan asing dengan persentase kepemilikan 25\% atau lebih, (3) Perusahaan sampel tidak mengalami kerugian selama periode pengamatan (2010-2012), dan (4) Perusahaan sampel mempunyai data laba/rugi selisih kurs.

Berdasarkan kriteria tersebut terpilih sampel sebanyak 84 selama 3 tahun. Adapun proses pemilihan sampel disajikan pada Tabel 1.

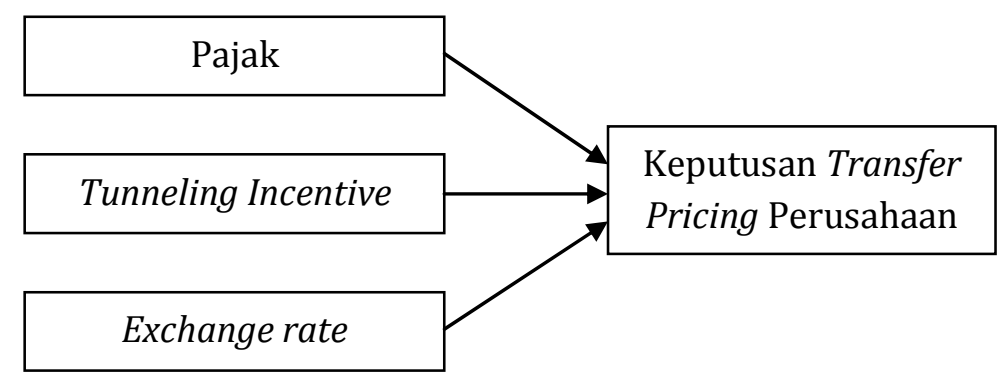

Gambar 1: Model kerangka pemikiran penelitian

Tabel 1: Proses Pemilihan Sampel

\begin{tabular}{|c|c|c|c|}
\hline Keterangan & 2010 & 2011 & 2012 \\
\hline $\begin{array}{l}\text { Perusahaan manufaktur yang terdaftar di Bursa Efek } \\
\text { Indonesia }\end{array}$ & 135 & 137 & 137 \\
\hline $\begin{array}{l}\text { Perusahaan tidak memiliki kepemilikan saham di atas } \\
25 \% \text { sebagai pemegang saham pengendali oleh } \\
\text { perusahaan asing. }\end{array}$ & (76) & (73) & (73) \\
\hline Perusahaan sampel yang mengalami kerugian usaha & $(12)$ & $(12)$ & $(17)$ \\
\hline $\begin{array}{l}\text { Perusahaan sampel yang tidak memiliki laba/ rugi } \\
\text { selisih kurs }\end{array}$ & (11) & (22) & $(29)$ \\
\hline Jumlah Sampel Akhir & 36 & 30 & 18 \\
\hline
\end{tabular}




\section{Jenis Data dan Sumber Data}

Jenis data yang digunakan dalam penelitian ini adalah data sekunder yang berupa data laporan tahunan (annual reports) perusahaan manufaktur pada periode pelaporan tahun 2010 hingga tahun 2012 dan Indonesia Capital Market Dictionary (ICMD). Annual reports dan ICMD tersebut didapat dari pojok Bursa Efek Indonesia (BEI) Universitas Islam Indonesia dan melalui websitewww.idx.co.id .

\section{Variabel dan Pengukurannya}

\section{Variabel Dependen}

Variabel dependen dalam penelitian ini adalah transfer pricing. Keberadaan variabel transfer pricing didasarkan pada ada/tidaknya data penjualan pada pihak yang mempunyai hubungan istimewa (Yuniasih, Rasmini, dan Wirakusuma 2012). Perusahaan yang melakukan penjualan pada pihak yang mempunyai hubungan istimewa diberi nilai 1 dan perusahaan yang tidak melakukan penjualan pada pihak yang mempunyai hubungan istimewa diberi nilai 0 .

\section{Variabel Independen}

Variabel independen dalam penelitian ini terdiri dari pajak, tunneling incentive dan exchange rate.

\section{Pajak}

Variabel pajak dalam penelitian ini dihitung dengan effective tax rate yang merupakan perbandingan tax expense dikurangi dengan differed tax expense kemudian dibagi dengan laba kena pajak (Yuniasih, Rasmini, dan Wirakusuma 2012).

$$
\begin{aligned}
& \text { Effective tax rate } \\
& =\frac{\text { Tax expense }- \text { deffered tax expense }}{\text { Laba ekna pajak }}
\end{aligned}
$$

\section{Tunneling Incentive}

Variabel tunneling incentive diukur dengan menggunakan persentase kepemilikan saham di atas $25 \%$ sebagai pemegang saham pengendali oleh perusahaan asing.

\section{Exchange Rate}

Seperti dalam penelitian Chan, Landry, dan Jalbert (2002), variabel exchange rate diukur dari keuntungan atau kerugian transaksi perusahaan yang menggunakan mata uang asing. Exchange rate dihitung dari laba atau rugi selisih kurs dibagi dengan laba atau rugi penjualan dengan rumus berikut ini:

\section{Exchange rate}

$$
=\frac{\text { Laba rugi selisih } k u r s}{\text { Laba rugi sebelum pajak }}
$$

\section{Metode Analisis Data}

Alat analisis yang digunakan untuk menguji hipotesis penelitian adalah analisis regresi logistik (Binary Logistic Regresion). Teknik ini digunakan karena variabel dependen dalam penelitian ini yaitu transfer pricing merupakan variabel dummy. Adapun model regresi logistik disajikan dalam persamaan sebagai berikut:

$$
\begin{aligned}
\operatorname{Logit}(\mathrm{Y})= & \ln \left[\frac{\boldsymbol{Y}}{1-Y}\right]=\beta_{0}+\beta_{1} x_{1}+\beta_{2} x_{2} \\
& +\beta_{3} x_{3}+\mathrm{e}
\end{aligned}
$$

Keterangan:

$\mathrm{Y} \quad=$ transfer pricing

$\beta_{0} \quad=$ Konstanta

$\beta_{1}-\beta_{3}=$ Koefisien Regresi

$\mathrm{X}_{1} \quad$ pajak

$\mathrm{X}_{2} \quad=$ tunneling incentive

$\mathrm{X}_{3}=$ exchange rate

e $\quad=$ Error Term, yaitu tingkat kesalahan penduga dalam penelitian

Kriteria pengujian hipotesis dalam penelitian ini adalah Ho ditolak jika nilai signifikansi Wald $<0,05$ dan masing-masing koefisien regresi sesuai dengan arah yang diprediksikan. Uji sig-Wald digunakan untuk mengetahui apakah variabel independen mempengaruhi variabel dependen di dalam model regresi logistik.

\section{HASIL DAN PEMBAHASAN}

Bagian ini membahas hasil penelitian dan pembahasan yang meliputi statistik deskriptif, uji multikoliearitas, analisis regresi logistik dan uji hipotesis. 


\section{Statistik Deskriptif}

Statistik deskriptif ini menggambarkan tentang data masing-masing variabel yang terdiri dari nilai minimum, maksimum, rata-rata, dan standar deviasi. Data yang diteliti dalam analisis statistik deskriptif adalah transfer pricing, pajak, tunneling incentive, dan exchange rate. Hasil dari deskriptif statistik dapat dilihat pada Tabel 2.

Berdasarkan Tabel 2, rata-rata variabel transfer pricing adalah 0,75 artinya $75 \%$ dari 84 sampel atau sebanyak 63 perusahaan sampel memiliki hubungan istimewa. Variabel pajak mempunyai nilai rata-rata 0,287122 , standar deviasi 0,2204298 dengan nilai minimum dan maksimum masing-masing sebesar 0,5207 dan 1,1838. Variabel tunneling incentive mempunyai nilai rata-rata 0,578488 dengan nilai minimum dan maksimum masing-masing adalah 0,2500 dan 0,9914. Exchange rate mempunyai nilai standar deviasi 0,9788911, nilai rata-rata $-0,089109$ dengan nilai minimum dan maksimum masing-masing adalah -7,4923 dan 1,4037.

\section{Uji Multikolinearitas}

Model regresi yang baik adalah regresi dengan tidak adanya gejala korelasi yang kuat di antara variabel bebasnya. Pengujian multikolinearitas dalam regresi logistik menggunakan matriks korelasi antar variabel bebas untuk melihat besarnya korelasi antar variabel bebas. Hasil pengujian dapat dilihat pada Tabel 3.

Hasil pengujian menunjukkan bahwa tidak ada nilai koefisien korelasi antar variabel yang lebih besar dari 0,8. Dengan demikian dapat disimpulkan bahwa tidak terdapat gejala multikolinearitas yang serius antar variabel bebas tersebut.

\section{Analisis Regresi Logistik}

Hasil uji hipotesis penelitian dengan model regresi logistik disajikan pada Tabel 4.

Persamaan Regresi:

$Y=0,662-3,460 X_{1}+2,656 X_{2}-0,433 X_{3}$

Tabel 2: Analisis Statistik Deskriptif

\begin{tabular}{lcccc}
\hline \multicolumn{1}{c}{ Variabel } & Nilai Minimum & Nilai Maksimum & Rata - rata & Standar Deviasi \\
\hline Transfer Pricing $(Y)$ & 0 & 1 & 0,75 & 0,436 \\
Pajak $(X 1)$ & $-0,5207$ & 1,1838 & 0,287122 & 0,2204298 \\
Tunneling Incentive $(X 2)$ & 0,2500 & 0,9914 & 0,578488 & 0,2124351 \\
Exchange rate $(X 3)$ & $-7,4923$ & 1,4037 & $-0,089109$ & 0,9788911 \\
\hline
\end{tabular}

Tabel 3: Hasil Uji Multikolinearitas dengan Matriks Korelasi

\begin{tabular}{lcccc}
\hline & Constant & Pajak & Tunneling Incentive & Exchange rate \\
\hline Constant & 1,000 & $-0,356$ & $-0,782$ & $-0,071$ \\
Pajak & $-0,356$ & 1,000 & $-0,195$ & 0,204 \\
Tunneling Incentive & $-0,782$ & $-0,195$ & 1,000 & $-0,033$ \\
Exchange rate & $-0,071$ & 0,204 & $-0,033$ & 1,000 \\
\hline
\end{tabular}

Tabel 4: Hasil Uji Regresi Logistik

\begin{tabular}{lccrrrrl}
\hline \multicolumn{1}{c}{ Variabel } & Prediksi & B & S.E. & Wald & Sig. & Exp(B) & \multicolumn{1}{c}{ Kesimpulan } \\
\hline Pajak (X1) & + & $-3,460$ & 1,367 & 6,403 & 0,011 & 0,031 & Ha1 tidak didukung \\
Tunneling Incentive (X2) & + & 2,656 & 1,318 & 4,059 & 0,044 & 14,24 & Ha2 didukung \\
Exchange rate (X3) & + & $-0,433$ & 0,364 & 1,418 & 0,234 & 0,648 & Ha3 tidak didukung \\
Constant & & 0,662 & 0,789 & 0,706 & 0,401 & 1,939 & Ha4 tidak didukung \\
\hline
\end{tabular}

Hosmer and Lemeshow Test: Chi-square $=4,108 ;$ Sig. $=0,847$

Overall Model Fit Test : -2 Log Likehood Block Number $=0$ adalah 94,472,

-2 Log Likehood Block Number $=1$ adalah 83,236

Nagel Karke R Square : 0,185

Cox \& Snell R Square :0,125 
Langkah pertama yang dilakukan adalah menilai kelayakan model regresi. Berdasakan hasil uji Hosmer and Lemeshow diperoleh nilai Chi-square sebesar 4,108 dengan sig 0,847 . Hal ini menunjukkan bahwa model mampu memprediksi nilai observasi karena cocok dengan data observasinya. Langkah kedua adalah menilai keseluruhan model regresi dengan membandingkan nilai -2 Log Likelihood Block Number $=0$ dan -2 Log Likelihood Block Number $=1$. Adanya penurunan yang signifikan nilai $-2 \quad \log$ Likelihood Block Number $=0$ sebesar 94,472 menjadi 83,236 pada model -2 Log Likelihood Block Number $=1$, menunjukkan bahwa model regresi dengan memasukkan semua variabel independen lebih baik atau dengan kata lain model yang dihipotesiskan fit dengan data. Langkah selanjutnya adalah menguji pengaruh dari masing-masing variabel independen terhadap variabel dependennya.

\section{Pengaruh Pajak Terhadap Keputusan Transfer Pricing Perusahaan}

Berdasarkan tabel di atas, diketahui besarnya koefisien regresi variabel pajak sebesar $-3,460$ dengan nilai sig- Wald sebesar 0,011. Oleh karena itu hipotesis pertama yang menyatakan bahwa pajak berpengaruh positif terhadap keputusan transfer pricing perusahaan tidak didukung, karena berdasarkan pengujian hipotesis tersebut pajak justru berpengaruh negatif signifikan terhadap keputusan transfer pricing.

Hasil ini mengindikasikan bahwa semakin meningkatnya pajak yang dikenakan maka perusahaan dalam melakukan transfer pricing dengan pihak yang mempunyai hubungan istimewa akan menurun atau sebaliknya. Hasil ini tidak sesuai dengan penelitian yang dilakukan oleh Yuniasih, Rasmini, dan Wirakusuma (2012) yang menemukan adanya pengaruh positif pajak terhadap keputusan transfer pricing perusahaan. Artinya beban pajak yang semakin besar memicu perusahaan untuk melakukan transfer pricing dengan harapan dapat menekan beban tersebut.

Hasil penelitian ini sesuai dengan penelitian yang dilakukan oleh Harimurti
(2007) yang menyatakan bahwa otoritas fiskal (aparat perpajakan) secara subyektif memandang tujuan dilakukannya transfer pricing adalah untuk menghindari pajak. Terkait dengan isu transfer pricing, secara umum otoritas fiskal harus memperhatikan dua hal mendasar agar koreksi pajak terhadap dugaan transfer pricing mendapat justifikasi yang kuat sehingga perusahaan dapat meminimalkan praktik transfer pricing. Kedua hal prinsipil tadi adalah; (1) afiliasi (associated enterprises) atau hubungan istimewa (special relationship) dan (2) kewajaran atau arm's length principle.

Dengan diadakannya kesepakatan transfer pricing antara wajib pajak dengan Direktorat Jendral Pajak kepada pihak-pihak yang mempunyai hubungan istimewa maka dapat mengurangi terjadinya praktik penyalahgunaan transfer pricing oleh perusahaan multinasional. Kesepakatan transfer pricing adalah kesepakatan antara wajib pajak dengan Direktorat Jendral Pajak kepada pihak-pihak yang mempunyai hubungan istimewa.

Prinsip kewajaran dan kelaziman usaha (Arm's Length Principle/ALP) merupakan prinsip yang mengatur bahwa apabila kondisi dalam transaksi yang dilakukan antara pihak-pihak yang mempunyai hubungan istimewa sama atau sebanding dengan kondisi dalam transaksi yang dilakukan antara pihakpihak yang tidak mempunyai hubungan istimewa yang menjadi pembanding, maka harga atau laba dalam transaksi yang dilakukan antara pihak-pihak yang mempunyai hubungan istimewa harus sama dengan atau berada dalam rentang harga atau laba dalam transaksi yang dilakukan antara pihak-pihak yang tidak mempunyai hubungan istimewa yang jadi pembanding. Hal tersebut telah diatur dalam Peraturan Dirjen Pajak No.PER42/PJ/2011. Aturan ini membahas tentang penerapan prinsip kewajaran dan kelaziman usaha (arm's length principal) terkait transaksi antara wajib pajak dengan pihak yang memiliki hubungan istimewa. Aturan ini mengharuskan wajib pajak untuk menggunakan nilai pasar wajar dalam bertransaksi dengan pihak istimewa (related pasties). 
Menurut arm's length principle, hargaharga transfer seharusnya ditetapkan supaya dapat mencerminkan harga yang disepakati meski transaksi tersebut dilakukan oleh pihakpihak yang tidak memiliki hubungan istimewa. Sehingga apabila ada transaksi antar perusahaan yang memiliki hubungan istimewa maka kondisi transaksi tersebut harus sama dengan transaksi antar perusahaan yang tidak memiliki hubungan istimewa.

\section{Pengaruh Tunneling Incentive Terhadap Keputusan Transfer Pricing Perusahaan}

Besarnya koefisien regresi variabel tunneling incentive yaitu 2,656 dengan nilai sig-Wald sebesar 0,044. Hal ini menunjukkan bahwa hipotesis kedua yang menyatakan tunneling incentive berpengaruh positif terhadap keputusan transfer pricing perusahaan, didukung. Hal ini menunjukkan bahwa semakin meningkatnya praktik tunneling incentive maka perusahaan akan lebih banyak melakukan transfer pricing dengan pihak yang mempunyai hubungan istimewa.

Penelitian ini sesuai dengan yang dilakukan oleh Mutamimah (2009) yang menyatakan bahwa tunneling lebih besar terjadi pada struktur kepemilikan terkonsentrasi tinggi dibanding pada struktur kepemilikan terkonsentrasi rendah. Dengan kata lain, tunneling lebih besar dilakukan pada pemegang saham mayoritas daripada pemegang saham minoritas. Tunneling pada struktur kepemilikan terkonsentrasi disebabkan oleh beberapa hal. Pertama, pemegang saham mayoritas mempunyai insentif dan kemampuan untuk melakukan transaksi-transaksi dengan harga tertentu. Kedua, lemahnya perlindungan hak-hak pemegang saham minoritas. Ketiga, pemegang saham mayoritas mempunyai kekuatan untuk mempengaruhi manajemen dalam membuat keputusan-keputusan yang hanya memaksimumkan kepentingan pemegang saham mayoritas dan merugikan kepentingan pemegang saham minoritas.

Tunneling incentive dilakukan oleh pemegang saham pengendali untuk memperoleh manfaat privat yaitu transfer sumber daya keluar dari perusahaan untuk kepentingan pemegang saham pengendali. Perusahaan melakukan tunneling ini dengan tujuan untuk meminimalkan biaya transaksi. Dengan melakukan tunneling kepada pihak yang memiliki hubungan istimewa maka biaya dapat ditekan sehingga lebih ekonomis dibandingkan dengan pihak yang tidak memiliki hubungan istimewa. Selain itu, perusahaan melakukan tunneling dengan tujuan untuk memanipulasi laba. Misalnya, perusahaan men-tunnel asetnya kepada pihak yang memiliki hubungan istimewa yang menyebabnya piutang kepada pihak yang memiliki hubungan istimewa meningkat sehingga dapat diinterpretasikan sebagai kenaikan laba.

Tunneling juga dapat dilakukan dengan cara menjual produk perusahaan kepada perusahaan yang memiliki hubungan dengan manajer dengan harga yang lebih rendah dibandingkan harga pasar, mempertahankan posisi/jabatan pekerjaanya meskipun mereka sudah tidak kompeten atau berkualitas lagi dalam menjalankan usahanya atau menjual asset perusahaan kepada perusahaan yang memiliki hubungan dengan manajer (pihak terafiliasi).

Sesuai dengan penelitian yang dilakukan oleh Sari (2012), ada dua hal yang dipertimbangkan sebagai dorongan bagi perusahaan untuk melakukan tunneling. Pertama, struktur kepemilikan. Kedua, tersedianya sumber daya keuangan pada perusahaan yang akan di-tunnel. Dengan pengendalian dan pengaruh signifikan yang dimiliki, pemegang saham pengendali dapat mengambil kebijakan yang menguntungkan dirinya, termasuk kebijakan kontraktual dengan pihak yang memiliki hubungan istimewa. Ketersediaan sumber daya juga akan menjadi dorongan bagi pemegang saham pengendali untuk men-tunnel sumber daya tersebut keluar dari perusahaan untuk kepentingan pemegang saham pengendali.

\section{Pengaruh Exchange rate Terhadap Keputusan Transfer Pricing Perusahaan}

Besarnya koefisien regresi variabel exchange rate yaitu $-0,433$ dengan nilai sig-Wald sebesar 0,234. Hal ini menunjukkan bahwa 
hipotesis ketiga yang menyatakan bahwa exchange rate berpengaruh positif terhadap keputusan transfer pricing perusahaan, tidak didukung. Artinya besar-kecilnya exchange rate tidak mempengaruhi pertimbangan perusahaan apakah perusahaan akan memilih untuk melakukan keputusan transfer pricing atau memilih untuk tidak melakukan keputusan transfer pricing dalam perusahaan.

Hasil penelitian ini tidak sesuai dengan penelitian yang dilakukan oleh Chan, Landry, dan Jalbert (2002) yang menemukan bahwa perusahaan multinasional mungkin mencoba untuk mengurangi risiko nilai tukar (exchange rate) mata uang asing dengan memindahkan dana ke mata uang yang kuat melalui transfer pricing untuk memaksimalkan keuntungan perusahaan secara keseluruhan. Tidak didukungnya hipotesis ketiga ini kemungkinan disebabkan karena dalam laporan keuangan sampel perusahaan, banyak terdapat kerugian pada laba atau rugi selisih kurs sehingga exchange rate tidak menjadi sorotan pokok dalam kecenderungan manajemen memanfaatkan transaksi transfer pricing.

\section{SIMPULAN}

Berdasarkan hasil analisis regresi logistik disimpulkan bahwa dari ketiga hipotesis yang diuji, hanya hipotesis kedua tentang pengaruh positif tunneling incentive terhadap transfer pricing yang didukung. Pengujian terhadap hipotesis pertama tentang pengaruh positif pajak terhadap transfer pricing, hasilnya justru berlawanan arah dengan yang diprediksikan, yaitu pajak berpengaruh negatif signifikan terhadap keputusan transfer pricing perusahaan. Hasil ini menunjukkan bahwa semakin tinggi tarif pajak yang dikenakan maka akan menurunkan keputusan transfer pricing perusahaan atau sebaliknya.

Pengujian terhadap hipotesis ketiga tentang pengaruh exchange rate terhadap transfer pricing menunjukkan arah yang positif tetapi tidak signifikan. Hasil ini mengindikasikan bahwa besar-kecilnya exchange rate tidak mempengaruhi pertimbangan perusahan apakah perusahaan akan memilih untuk melakukan keputusan transfer pricing atau memilih untuk tidak melakukan keputusan transfer pricing dalam perusahaan.

Penelitian ini menggunakan sampel dari perusahaan manufaktur tanpa membedakannya antar sektor industri, yang meliputi sektor industri dasar dan kimia, sektor aneka industri, dan sektor industri barang konsumsi. Penelitian berikutnya dapat mengembangkan penelitian ini dengan membandingkan antar sektor industri dalam perusahaan manufaktur sehingga akan diperoleh hasil yang lebih teliti yang memungkinkan hasil yang berbeda di setiap sektor industri tersebut, karena tiap sektor industri mempunyai karakteristik yang berbeda.

\section{DAFTAR REFERENSI}

Anthony, N.R., dan V. Govindarajan. 2011. Sistem pengendalian manajemen jilid 2. Tangerang: Kharisma Publishing Group.

Chan, C., S. P. Landry, dan T. Jalbert. 2002. Effects of exchange rate on international transfer pricing decisions. International Bussiness \& Economics Research Journal 3 (3): 35-48

Eiteman, D. K., A. I. Stonehill, dan M. H. Moffett . 2010. Multinational Business Finance 12th edition. Pearson. (ESM).

Harimurti, F. 2007. Aspek perpajakan dalam praktik transfer pricing. Jurnal Ekonomi dan Kewirausahaan 7 (1): 53-61

Johnson, S., R. La Porta, F. Lopez-de-Silanes, dan A. Shleifer. 2000. Tunneling. American Economic Review 90 (2): 22-27.

Mangoting, Y. 2000. Aspek perpajakan dalam praktek transfer pricing. Jurnal Akuntansi \& Keuangan 2 (1): 69-82

Mutamimah. 2009. Tunneling atau value added dalam strategi merger dan akuisisi di indonesia. Jurnal Manajemen Teori dan Terapan 2 (2): 161-182

Gilson, R. J., dan J. N. Gordon. 2003. Controlling Controlling Shareholders. Columbia Law School The Center for Law and Economic Studies 435 West 116th St. New York, NY 10027-7201 Working Paper No. 228. June 2003. 
http://www.law.columbia.edu/center_p rogram/law_economics/ (diakses 14 Maret 2014)

Santoso, I. 2004. Advance pricing agreement dan problematika transfer pricing dari perspektif perpajakan indonesia. Jurnal Akuntansi dan Keuangan 6 (2): 123-139

Sari, R. C. 2012. Tunneling dan Model Prediksi: Bukti Empiris pada Transaksi
Pihak Berelasi. Disertasi. Yogyakarta: Universitas Gadjah Mada.

Yuniasih, N. W., N. K. Rasmini, dan M. G. Wirakusuma. 2012. Pengaruh pajak dan tunneling incentive pada keputusan transfer pricing perusahaan Manufaktur yang listing di bursa efek indonesia. Simposium Nasional Akuntansi 15. 